\title{
The linguistic landscape of the coronavirus crisis in foreign language didactics by using the example of German
}

\author{
Holger Kuße*
}

Slavic Languages and Linguistics, Institute for Slavic Studies, TU Dresden, 01062 Dresden

\begin{abstract}
The coronavirus crisis has changed not only the practice of language teaching in higher education, but also the languages themselves; the crisis is strongly reflected in language. This can be seen in neologisms, new word formations and in the linguistic landscape in general. All these phenomena should be creatively included in foreign language didactics. Using examples from German the paper deals with several tasks and exercises concerning the language of the corona crises, i.e. word formation, word play, forms of politeness and the communication of values.
\end{abstract}

\section{Introduction}

Put simply, the coronavirus pandemic has changed life at universities. Teaching has become largely digital and must therefore rely even more on the independence and creative skills of students than was already the case in the modern teaching practice in higher education. This is especially true in foreign language education. The task of foreign language didactics is to use these challenges as opportunities. In the coronavirus pandemic, this means concretely: its widely visible linguistic impacts should be included in language teaching.

The following topics in particular can be addressed: (1) vocabulary and word formation, (2) wordplay and humour, (3) politeness and values. Students should search for and evaluate material on the different topics. This should be achieved by creating corpora from the Internet, documenting linguistic landscapes in the public sphere and reflecting on existing studies. The evaluation of materials from the linguistic landscape is particularly important. Language in the public space has received increasing attention in linguistics in recent years $[1,2,3]$, and is also suitable for language teaching, since posters, signs, etc. often contain very concise forms that reveal much about contemporary language use. The coronavirus crisis has also left clear traces on the linguistic landscape $[3,4]$ that can be documented by students in Germany themselves. As an outcome, posters, signs, inscriptions and other elements of linguistic landscape can be shown and commented on in a poster exhibition or in internet exhibitions on the seminar's website. For students outside Germany, teachers should send photographs of the German linguistic landscape directly to them.

\section{Vocabulary and word formation}


The coronavirus pandemic has generated a large number of new words and word formations in all languages. The words Coronavirus and Pandemie (Pandemic) were nearly unknown in German at the beginning of 2020. In addition, there are new anglicisms such as Social Distancing and Homeschooling, and another anglicism Homeoffice has in particular become widespread. There are neologisms such as Herdenimmunität (herd immunity), and new administrative terms such as Hygieneabstand (hygiene distance) or Abstands- und Hygieneregeln (distance rules and hygiene rules) have entered the everyday language. Furthermore, some words have acquired a special meaning. This applies, for example, to the word Risikogebiet (risk area). The word does not say what risk is particularly high in an area, but today the meaning 'area with an increased risk of infection with the coronavirus' is connoted above all. The word Corona has in general become a productive root in the German composite. The root has shed its second, appellative part -virus in the process, and has been replaced by specifiers such as -krise (crisis) or -zahlen (numbers). These neologisms are formed as real compounds or as binomina with a hyphen. In many cases both forms are possible, e.g. Coronakrise and Corona-Krise. Common composites are Coronaregel (corona rule), Coronazahlen (corona numbers), Coronaausbruch (corona outbreak), Coronasymptome (corona symptoms). Binomina show great variety: CoronaInfektion (corona infection), Corona-Situation (corona situation), Corona-Schutz (corona protection), Corona-Maßnahmen (corona measures), Corona-Ferien (corona holidays), Corona-Nachrichten (corona news), Corona-App (corona app), Corona-Leugner (corona denier), Corona-Leugner-Demo (corona denier demonstration) etc.

Students shall:

Collect and classify material by themselves: Anglicisms, neologisms, compound formations, binomina, etc.

Compare German word formations with other languages they know.

Students can use various tools. For German, the publications of the Institute for the German Language in Mannheim (IDS), which are freely accessible on the Internet (https://www1.ids-mannheim.de/sprache-in-der-coronakrise/), are particularly helpful. Depending on the language level of the students, these texts can be read and evaluated by themselves or prepared by the teacher and provided with translation aids. In the meantime, comparative language studies have also been published [5].

\section{Wordplay and Humor}

People always react to crises with humour. Teachers can discuss certain forms such as comedy or cartoons, internet memes, etc. with students. For advanced students, the YouTube videos of the comedy couple Hazel and Thomas are suitable, especially Social Distancing Ep. 1: Bücher (Books) (https://www.youtube.com/ watch?v=2bnmDsAu068). This also works with shorter forms, especially with jokes that can be found in large numbers on the Internet, e.g. at www.pinterest.de:

Sagt gerade ein Virologe im Fernsehen: Die beste Waffe im Kampf gegen das Coronavirus ist der gesunde Menschenverstand. Wir sind verloren! Die meisten von uns sind unbewaffnet.

A virologist is saying on TV right now: The best weapon in the fight against the coronavirus is common sense. We are doomed! Most of us are unarmed.

Suche asoziale Kontakte, soziale sind ja verboten.

I'm looking for asocial contacts, as social contacts are forbidden.

The examples are based on the polysemy of the word weapon, the use of the phraseme common sense and the intentional misinterpretation of the semantic contradiction of asocial and social. Furthermore, a typical form of such slogans is the literal interpretation of metaphors, as in the following example with the word Hamsterkauf (by which is meant 
metaphorically 'panic buying'): Because of Coronavirus, Hamsterkäufe is being advised according to the media. Now I have bought such a hamster. What now?

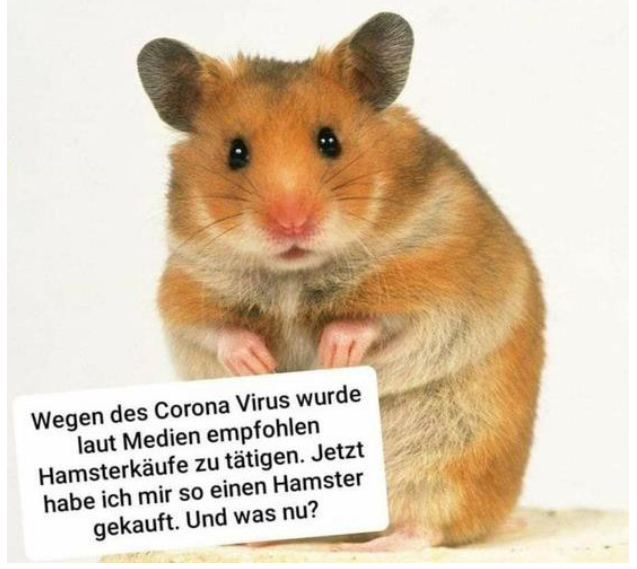

Fig.1

The phrase "according to the media" is particularly pertinent, as panic buying was advised against, i.e. exactly the opposite of what is claimed in the saying - an allusion to the widespread panic buying at the beginning of the first lockdown in March 2020.

Simple forms of wordplay can also be found in the linguistic landscape of public spaces. The predicative collocation Verantwortung tragen (to bear responsibility) and the prepositional construction mit Abstand (with distance) provoke wordplay. The double meaning of tragen for a physical activity (to wear) and a social role (to bear) makes Maske (mask) a contextual synonym for Verantwortung (responsibility). On the doors of buses and trams in the city of Dresden there are smilies with a mask and the inscription Verantwortung tragen! (Bear responsibility! = Wear a mask!). Additionally, a supermarket points out to customers at the entrance that bearing responsibility is standard today: Heute trägt man Verantwortung! (Today you bear responsibility! = Today you wear a mask!).

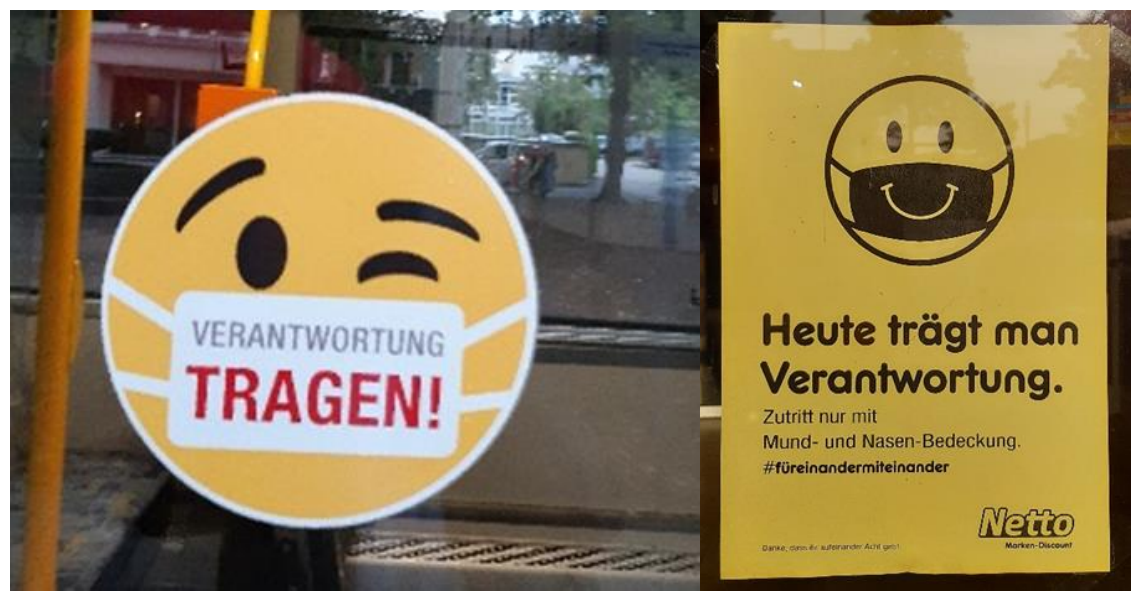

Fig. 2, photo: Holger Kuße

The request to bear responsibility is only clear with the associated illustration. In the case of mit Abstand (with distance) on the other hand, the double meaning is understandable because of the construction mit Abstand am besten / schönsten / schnellsten 
(by far the best / nicest / fastest), which in German reinforces the superlative. A café calls on its guests to keep their distance and at the same time advertises its cake as the best in town: Wir haben mit ABSTAND den besten Kuchen! (We have by far the best cake!).

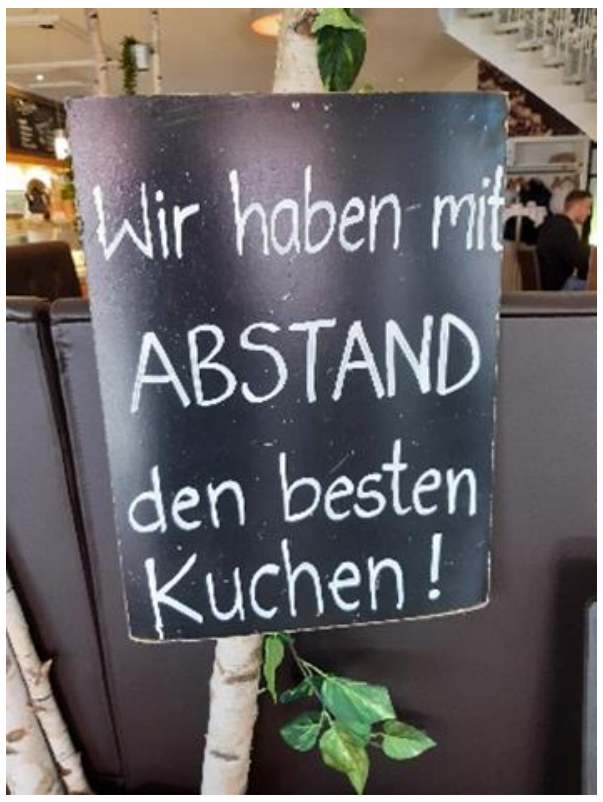

Fig.3, photo: Holger Kuße

Even the German government has been linguistically creative and created the AHA formula or AHA rule. In German, Aha is an expression of spontaneous realisation; a person realises something that they did not know before. There is the binomen Aha-Erlebnis (aha experience). However, the letter sequence A-H-A in the AHA rule also designates the first letters of the three words Abstand (distance), Hygiene (hygiene) and Alltagsmaske (everyday mask). The AHA formula is advertised on cityscape billboards:

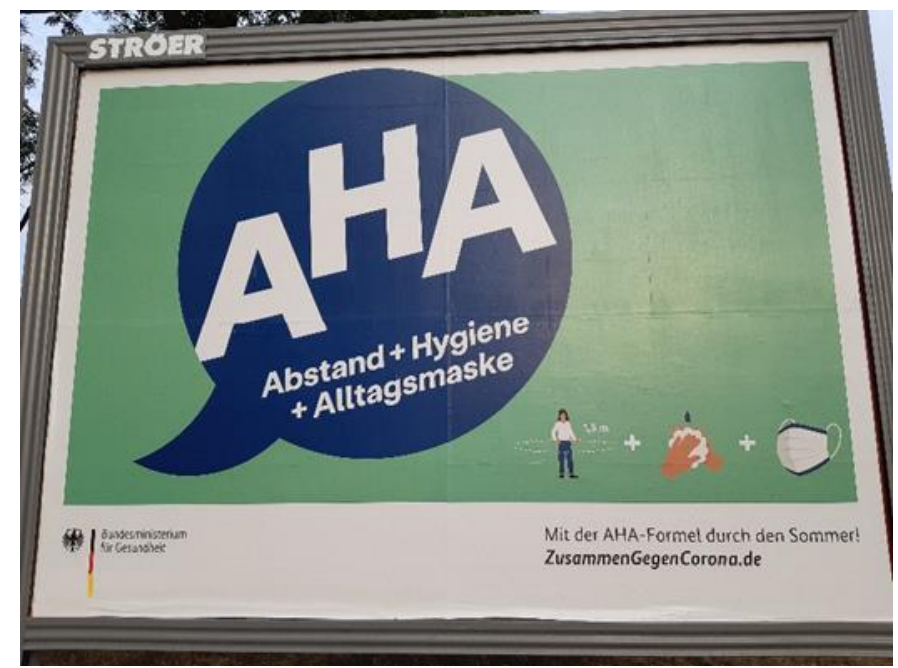

Fig. 4, photo: Holger Kuße 
The Gemäldegalerie Alte Meister (Old Masters Picture Gallery) in Dresden has an advertisement of a painting of Adam and Eve in paradise shortly before the forbidden consumption of the fruit from the tree of knowledge. Both are wearing facemasks. Between them, an arrow graphic illustrates the social distancing requirement of 2 metres. The poster plays with the double meaning of the phrase Mit Vorsicht zu genießen! (To be enjoyed with caution!), which means that a certain thing should only be approached with extreme carefulness. This meaning refers directly to the story of the fall. As a message for the museum visitor, however, the expression means nothing other than that the visitor is able to visit the painting gallery, but that he or she should do so with caution, and at the same time with due distance from each other and the paintings.

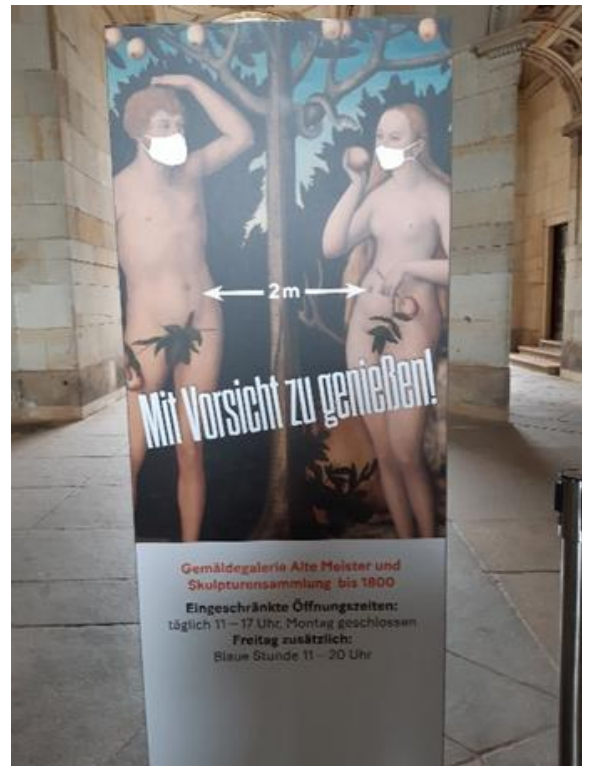

Fig.5, photo: Holger Kuße

Students shall:

Find examples of humour and wordplay in the context of the coronavirus crisis.

Distinguish word plays on the basis of collocations (Verantwortung tragen), double meanings (Mit Abstand am besten) and phraseologisms (Mit Vorsicht zu genießen!), and understand their semantics (idioms, metonyms, metaphors, contra-dictions, etc.).

\section{Politeness and values}

Throughout public spaces and in shops, two rules of conduct are particularly important: keeping distance from other people, and wearing a mask. The request to keep one's distance is expressed in its simplest form with the imperative infinitive Maske tragen (Wear a mask) or by the noun Maskenpflicht (Maskobligation). 


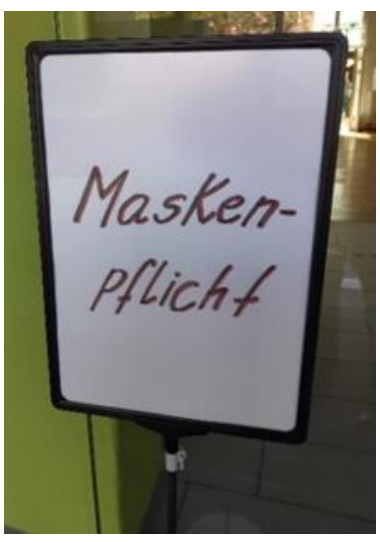

Fid.6, Photo: Holger Kuße

However, most cues in public spaces are characterised by various forms of politeness. These include the form of address, the explicit form of request, the avoidance of the word Pflicht (obligation) etc., as in the following example: Liebe Gäste, tragen Sie in den öffentlichen Bereichen bitte ihren Mundschutz (Dear guests, please wear your facemask in public spaces).

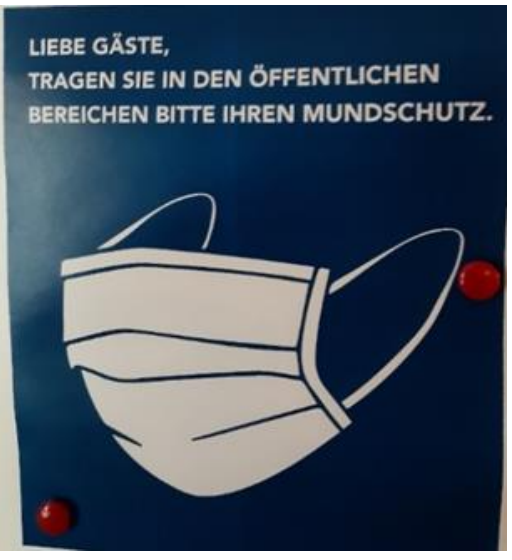

Fig.7, Photo: Holger Kuße

In these requests and instructions, it is not only rules of conduct that are prescribed, but also values. In the last example, this is accomplished with the word Schutz (protection), which refers to the value of safety. The most important values that appear in the linguistic landscape of the coronavirus crisis are safety, health, responsibility, and togetherness. The value responsibility is metonymically linked to the mask; cf. the word plays mentioned above with the collocation bear responsibility. Safety is a value often explicitly mentioned to justify the prescribed measures in public spaces (wearing a facemask, keeping one's distance); cf. a poster at Deutsche Bahn railway stations with the inscription $\mathrm{Zu}$ Ihrer und unserer Sicherheit (For your and our safety). 


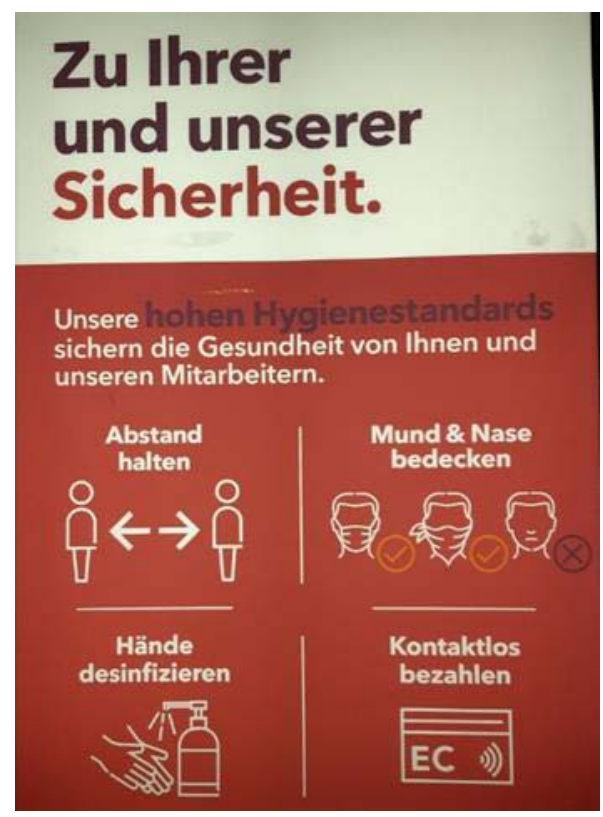

Fig.8, Photo: Holger Kuße

In these requests and references, people are sometimes addressed directly. In the following example, customers of a grocery shop are told that their health is of high value: Deine Gesundheit liegt uns am Herzen (Your health is close to our hearts). The poster has the function of politely asking people to wear a mask: Bitte pass auf dich auf und nutze einen Gesichtsschutz, Mundschutz oder Schal (Please take care of yourself and use a facemask, mouth mask or scarf).

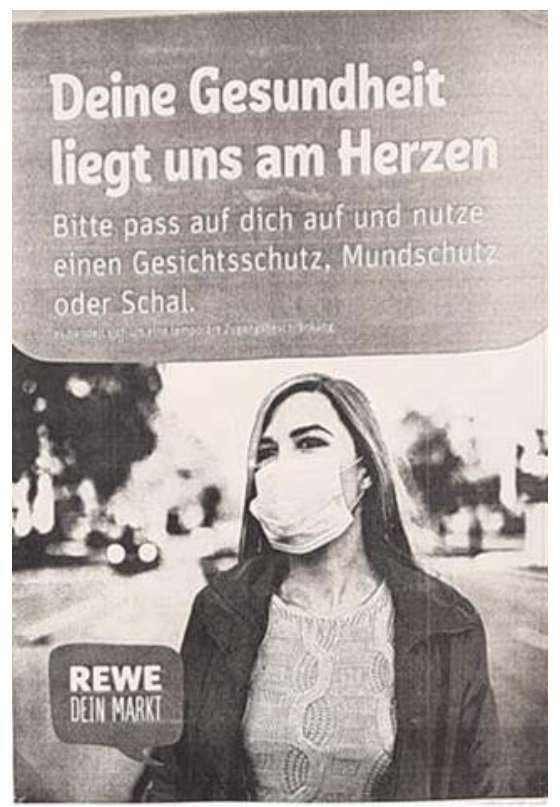

Fig.9, Photo: Holger Kuße 
The use of the idiomatic expression liegt uns am Herzen (is close to our hearts) indicates a dilemma in the communication of values. Distance and mask are expressions of responsibility and safety, but they are also a sign of distance and social separation. There are examples that respond to this value dilemma; e.g. Im Herzen nah trotz 1, 5 Meter Abstand (Close at heart despite 1, 5 metres distance).

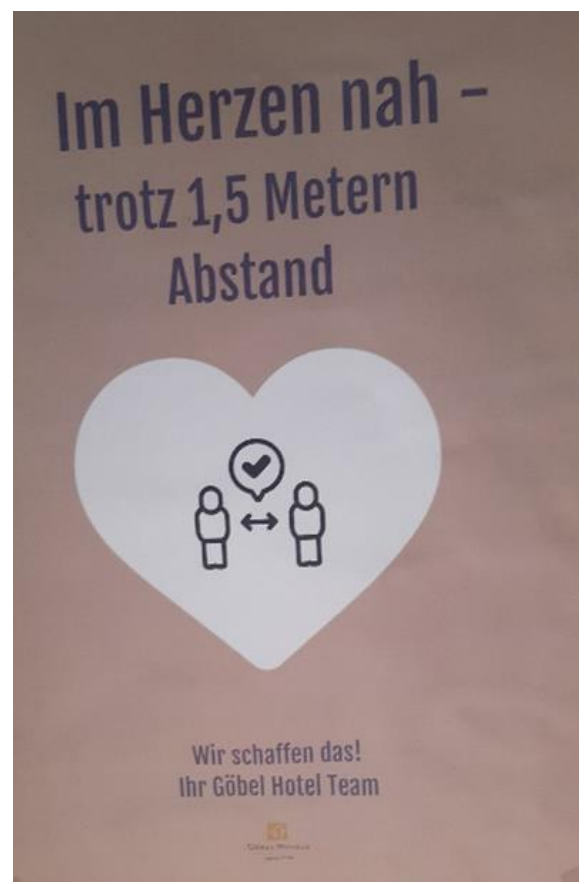

Fig.10, Photo: Holger Kuße

Keywords used in official communication to express social cohesion and community during the coronavirus pandemic have been the adverbs gemeinsam and zusammen (together). The collocation gemeinsam gegen Corona (together against corona) currently yields a hit rate of about 534,000 on Google, while zusammen gegen Corona has a hit rate of about 109,000 (13.12.2020). For instance, Deutsche Bahn has a website with the address www.gemeinsamgehtdas.de (together it works), and The Federal Ministry of Health provides information on the site www.zusammengegencorona.de/. There are similar websites in regional areas. For example, companies in the city of Leverkusen have formed a mutual aid network, the services of which can be seen on the site www.gemeinsam $\neg$ gegencorona.info/. The slogan on the homepage is Leverkusener halten zusammen (Leverkuseners hold together). 


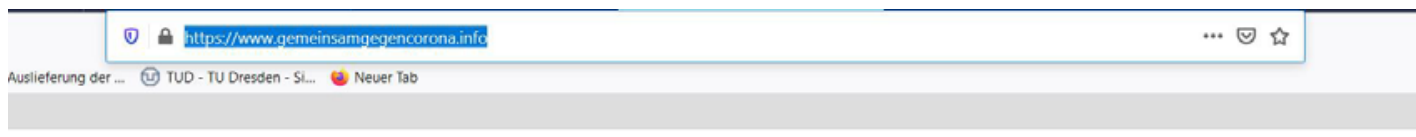

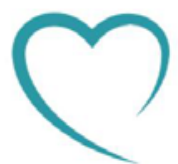

\section{Gemeinsam gegen Corona}

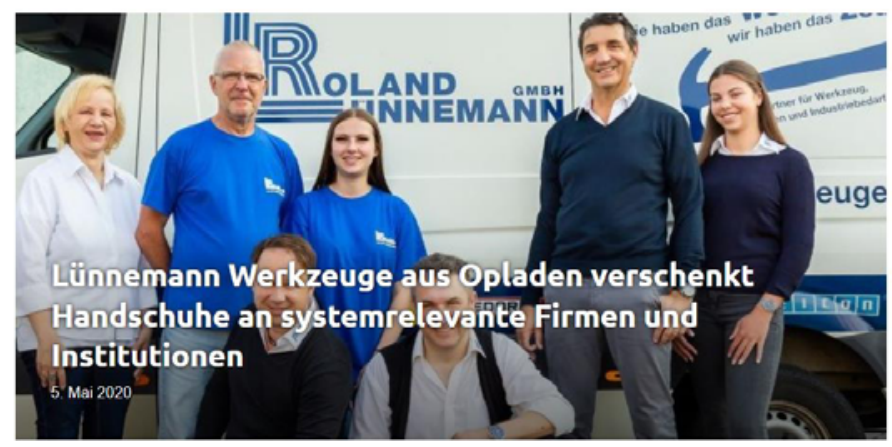

ACHTUNG

Die hier hinterlegten Daten kơnnen sich gerade tăglich ăndern.

Bitte informiere dich abschließend auf der Website des jeweiligen Anbieters über aktuelle Angebote und Offnungszeiten

Fig.11, www.gemeinsamgegencorona.info

There are hashtags like \#gemeinsamgegencorona, \#wirhaltenzusammen (we hold together) or \#besonderehelden (special heroes). All of this gives a lot of material that can be compiled by students and evaluated in collaboration.

Students shall:

Collect forms of politeness in the linguistic landscape and classify them according to degrees of politeness.

Distinguish forms of expressing values: e.g. the indirect expression of the value safety through the use of the word protection and its derivatives, the expression of value dilemmas through adversative or concessive constructions, and the expression of values in adjectives and adverbs.

\section{Conclusions}

The coronavirus pandemic has restricted public life. However, it has also greatly enriched the vocabulary and led to changes in the linguistic landscape. These phenomena are to be dealt with creatively in language teaching. The students' task should be to collect, classify and evaluate new language phenomena, whilst the target is to increase linguistic and cultural competences through creative work on current phenomena of language in interaction with the lecturer and independently, and to develop the competence to autonomously access current language developments. On this basis, small projects can be developed in which the students identify the special features and developments in the language of the coronavirus pandemic and present them publicly - for example, in the form of small exhibitions on the Internet or, when this is again possible, in the form of poster exhibitions. 


\section{References}

1. P. Backhaus, Linguistic Landscapes. A Comparative Study of Urban Multilingualism in Tokyo. Clevedon; Buffalo; Toronto: Multilingual Matters Ltd., 158 (2007)

2. L.L. Fedorova, Language landscape: city and crowd. Bulletin of Novosibirsk State University. Series: History, Philology. 6.70 (2014)

3. H. Kusset, Linguistic landscape of coronacrisis in Germany. Communication research. 4, 814 (2020) [http://www.com-studies.org/ru/]

4. A. Mueller, On the reflection of the pandemic in different cultural linguistic landscapes (on the example of elements of the public space of Minsk, Nuremberg and Warsaw). 4. 846 (2020) [http://www.com-studies.org/ru/]

5. A. Mustajoki, N. Zorikhina-Nilsson, A. Tous-Rovirosa, R. Guzman Tirado, D. Dergacheva, I. Vepreva, T. Itskovich, Covid-19: a catastrophe in the linguistic dimension of different countries. Quaestio Rossica. 4. 1369 (2020) [https://qr.urfu.ru/ojs/index.php/qr/issue/view/316/238] 